\title{
Psychological Foundations of the Formation of National Pride in Youth
}

\author{
FayzievaShoiraAyubovna \\ Gulistan State University ,Senior Lecturer of the Department of Pedagogy and Psychology
}

\begin{abstract}
This article sheds light on the psychological foundations of the formation of national pride in work. The feeling of pride is originated by psychological directions which are formed with the help of professionals dealing in this field. The pride in deeds, thoughts and spiritual wealth of one's ancestors, their people, is part of a sense of national dignity.
\end{abstract}

Key words: Pride, national pride, psychological foundations, contribution, society, tradition, education, motherland, patriotism, national identity.

\section{Introduction}

National pride is a display of a sense of high respect for its nation and national ethnopsychological characteristics, as well as the nation's contribution to world culture on the basis of awareness and conviction. National dignity is a manifestation of the boundless respect of the individual for his nationality, ethnopsychological features of his nation, awareness of the contribution of the nation to the world culture, devotion to the nation and implementation of practical activities for the benefit of its people.

\section{Main part}

In the years of independence, the wellbeing, level and quality of life of our people have been steadily improved. This is clearly manifested in the dynamic growth of incomes of the population, large-scale housing construction, provision of the domestic market with high-quality consumer goods, development of social infrastructure. Currently, 97\% of families in the country have their own housing, one in three families - a personal car. $90 \%$ of the population is provided with all basic durable goods. Uzbekistan has high enough places in terms of social wellbeing, including life expectancy, peace and family harmony, and low unemployment, which many countries of the world can envy. The education of a well-developed young generation has become a top priority of public policy.
Uzbekistan has created a unique mechanism for providing continuous education. Including in remote areas, built modern professional colleges, academic lyceums.

Large-scale measures, carried out on the basis of the concept of "Healthy Mother Healthy Child" put forward by the head of our state, are an important factor in strengthening the reproductive health of the population and forming a healthy family. In modern screening centers established in all regions of the country, the National Specialized Scientific and Practical Medical Center for Pediatrics and the Center for Reproductive Health, their regional branches provide high-skilled medical care to mothers and infants.

Particular attention is paid to the development of sport as an integral part of educating the younger generation with harmoniously developed personalities, affirmation in society of a healthy lifestyle. The activities of the Foundation for the Development of Children's Sports of Uzbekistan, created on the initiative of the President of our country Shavkat Mirziyoyev, have become a national movement, serving both physical and spiritual development of young people.

During the years of independence, the country has consistently implemented large-scale comprehensive reforms aimed at building a democratic state and a strong civil society. The Constitution of the Republic of Uzbekistan stipulates that a 
person, his life, freedom, honor, dignity and other inalienable rights are the highest value. We can see the realization of these fundamental norms by the realization of the hopes and aspirations of every person, every family, the expanding worldview of people, their attitude to life and work.

At the initiative of the head of state, the anniversaries of such our great ancestors as Amir Temur, Mirzo Ulugbek, Jaloliddin Manguberda and Alisher Navoi were widely celebrated. The burial sites are well-maintained and the names of outstanding scientists and thinkers are immortalized: Imam Bukhari, Abduholika Gizhduponi, Bahouddin Naqshband, Imam Termezi, Imam Moturidi, Ahmad Fargooni, Burhoniddin Margino-ni. The tradition has become a celebration on an international scale in the country of the anniversaries of our ancient and eternally young cities, whose history dates back more than one millennium - Samarkand, Khiva, Bukhara, Shahrisabza, Karshi, Termez, Tashkent, Margilan. Our hearts are filled with a sense of boundless pride that we are the descendants of such outstanding ancestors. The international music festival "Shark Taronalari" servedandso broad propaganda of our rich spiritual heritage, support of the creative intelligentsia, which operates in various areas of art.

At all stages of the system of continuing education, special attention is paid to the formation of national pride among young people, which has a special social and educational significance.

Each nation exists through a system of stable internal relations and relationships of its people. These links and attitudes are formed in the process of ethnic development, are governed by traditions and norms of behaviour adopted in this environment, and are improved as the original national culture, language and psychology develops.

The objective basis of the nation's life is the need for interaction and communication between people during its economic, political development, exchange of cultural achievements, products and results of work. There is a tendency: the higher the intra-national and intra-group integration, the more visible the achievements in the economy and culture, the more intense socio-political and intragroup contacts and communication between people.

One of the main signs of the existence of the nation is the historical memory, which is the covenants of antiquity, the legends of the fathers, the sense of monogenability, i.e. the involvement in the spiritual mission of a kind, the people, the nation, the Motherland. A person with a historical memory realizes his place in the spiritual baton of generations. From the barbarian it distinguishes "love for native ashes, love for paternal coffins." This love is not just poetic dreams, but the real basis of purpose. A representative of a nation can understand who he is only by remembering who his ancestors were. Historical memory materializes in tradition and way of life: cultural, religious, economic, state.

The possibility of a nation's long existence is conditioned by the functioning and constant improvement of its internal content, which is expressed in national consciousness and self-awareness, national values, interests, tastes and self-esteems, national culture and language. The manifestation of all these components is the life of the nation.

Each nation has its own national consciousness, expressed in a complex set of social, political, economic, moral, aesthetic, philosophical, religious and other views and beliefs, characterizing a certain level of its spiritual development. National consciousness is the product of long-term historical development, and its central component is national identity. The structure of national consciousness, in addition to the latter, includes other elements, such as the nation's awareness of the need for unity, integrity and cohesion in the name of realizing its interests, 
understanding the importance of ensuring good-neighbourly relations with other ethnic communities, the thrifty attitude of the nation to its material and spiritual values, etc.

National consciousness exists at the theoretical and ordinary levels. If the theoretical level of national consciousness is a scientifically framed, systematic structure consisting of ideological views, ideas, programs, norms, values, etc., developed by the nation during the long period of its existence and determining the strategy of its development, then the ordinary level of national consciousness includes needs, interests, values, attitudes, stereotypes, feelings, moods, customs and traditions of members of this community, manifested in everyday life. All these components are in close unity, they are inextricably linked with each other. It should be noted that ordinary national consciousness is the main psychological basis of various kinds of inter-ethnic tensions and conflicts, as it forms national prejudices, negative attitudes, intolerance to other communities.

Consciousness of society, group (public consciousness) consists of two interconnected parts: the theoretical level and the level of ordinary consciousness.

The theoretical level includes ideology: people's generalized views on life and society.

The level of ordinary consciousness includes social psychology: direct reactions of people to the impact of objective reality and life in society.

Forms of public consciousness are science, philosophy, morality, law, religion, culture.

In general, national consciousness has the following characteristics:

- the existence of a holistic ethnic picture of the world, a set of stable, coherent ideas and judgments about social existence, life and activities inherent in members of a particular ethnic community; . its "correct" transmission from generation to generation in the process of normal socialization developed by this ethnic community;

- determining of the whole holistic and complex perception of life by an ethnic community: social institutions; systems of personal and group (including professional) relations, rites and rituals, ideology, art and folklore; tankers (i.e. the image of representatives of their nation) that determine the internal politics of the ethnic group; heterostereotypes (i.e. the image of neighbors); systems of interethnic (in particular, and interstate) relations, i.e. paradigms of "foreign policy" of ethnic community (rules of conduct with representatives of "foreign" ethnic communities), etc.;

- its correlation with the behavioural stereotypes inherent in members of this ethnic group;

- its conformity to the social conditions of the ethnic community, the stage of its social development, the structure of life support (material basis), as well as the relationship between the ethnic picture of the world and the norms and values that dominate other peoples, which can be expressed as the inclusion of oneself in some inter-ethnic cultural unity or as an isolation, opposition to other peoples.

One of the most important priorities of public policy in Uzbekistan is the improvement of the national education system, focused "on the formation of a new generation of people with a high general and professional culture, creative and social activity, the ability to independently navigate in social and political life, able to set and solve problems for the future." [3, 4]

The education system plays a huge role in this important and complex process of the formation of a new generation of personnel. In this regard, the period of state independence in the general schools of Uzbekistan introduced new disciplines such as "Theory and practice of building a democratic society in Uzbekistan," "Theory and practice of human rights," "Foundation of spirituality," "The idea of 
national independence: basic concepts and principles."

The first President of our state noted the relevance of the topic: "... First there is an idea, then on its basis there is an ideology, on the basis of ideology a system is built, a policy".

Introduced new discipline "Idea of National Independence" in the schools of the Republic is aimed at the formation of a citizen, a patriot of his homeland, an active civic position, the development of skills of self-education and self-education, selfactualization.

The content of this discipline is as follows:

- becoming a criterion for the revival of historical memory, the ability to draw conclusions from the past;

The task of reflecting the fundamental interests of the people and uniting members of society;

Becoming a force for a unifying nation, people and society, a source of high trust;

To have the same treatment of all peoples, nations, nationalities, social strata and their representatives living in Uzbekistan;

- to serve the formation of the consciousness, our multi-ethnic people,

The idea of national independence, as a social phenomenon, a national phenomenon, is becoming a leading one on the ideologies of different political parties and social groups;

- not to absolutize any worldview, not to become a political tool in the hands of any force, party or group;

- to absorb all advanced ideas and be able to resist against all sorts of hostile forces;

- to become an objective ideology free from such vices as subjectivism, voluntarism, to rely on the unselfish thought of society;

- to be able to combine the word with the case, theory with practice;

- the ability to adjust in a timely manner, offering new means of implementing their interests and goals, adapting to a rapidly changing situation, to be resourceful and creative. $[5,12]$
The idea of national independence can only become a leader when it has the above qualities.

The most important task of the course is to promote the assimilation and mastery of youth ideology of national independence. Ideology is needed by every society, without it a person, a society, a state will lose landmarks in its path, will fail. "The ideology of national independence, based on the centuries-old traditions, customs, language and spirit of our people, closely combined with universal values, should serve to convey to the hearts and minds of people faith in the future, to cultivate love for the Motherland, humanity, courage and tolerance, a sense of justice, the desire for knowledge and enlightenment. It should help the citizens of the state to spiritually bring the citizens of the state closer together on the path to a great goal."

In this regard, the content of discipline is focused, first of all, on the progressive worldview, on the mentality of the part of the public that does not separate its destiny from the fate of the Motherland, sincerely worries about what is happening in the life of the country, fighting for its future. We are referring to the works of our great ancestors, such as Abu Nasr Farabi, Beruni, Ibn Sino, Ahmad Yassavi, Amira Timur, Alisher Navon. Bahauddin Naksh Band, Nazhmiddin Kubro. For example, when studying Farabi's famous work "City of Noble People" ("Fozil Odamlar Shahri"), high school students can learn important thoughts and instructions from this work to solve the complex problems of modern life, despite the fact that it was created a thousand years ago.

Particularly great spiritual development for high school students is given by the theme dedicated to the study of the life and activities of Amir Timur - a great personality: an invincible commander, a major statesman, a lawyer, a talented architect, a speaker. Great strategist, skilful politician, determined reformer, creator of the state based on laws and customs, 
philanthropist, patron of trade, craftsmanship, culture.

In the spiritual heritage of A. Timur is very useful for the younger generation, in particular in the preparation of young men for independent life useful study of the autobiography of Amir Timur, who writes about the moral qualities of a person as a person with a huge inner spiritual wealth and beauty, which boil down to the following:

At the heart of moral qualities must be selflessness;

- unquestioning observance of religious dogmas, respect for individuals revered by Allah's will;

- it is always necessary to make more donations to the poor, each quarrel should be carefully studied and, as far as possible, it should be solved positively;

- all activities to direct to the universal benefit and benefit. In this case, for no reason not to offend anyone, to render possible assistance to those who came to you for help;

Strictly adhere to justice;

- Never promise if you are unable to deliver on promises;

Never harm anyone for no reason.

- to consider himself a servant and a slave of Allah;

- strive to be the same with both the simple and the highest segments of the population;

- You should never envy someone else;

- Strictly observe the principles of the hadith of the prophet and Allah;

- To raise the banner of Islam high, to recognize the great power of the Tariqat of Faith: "I have heard that faith and power are born of one mother. Therefore, the power based on strong faith will be great." From these spiritual and moral qualities of the person described by A. Timur, the young men of high school can conclude that the just rule of the country, love for the people and courage, national pride of our ancestors, courageous fights with enemies for the honor of the Motherland and the nation were put above all, and that every young man must and must develop these qualities.

The study of the legendary historical personality of Jaloliddin Manguberda - the brave son of Khorezm is of great importance in the formation and improvement of the young men of high school such views as humanity, pride, a sense of devotion to the Motherland, boundless love for the Motherland: "The face of Khorezm you must see your mother!" [2, 178]

Studying the heroism of Jaloliddin Manguberda, the students understand how great his love for the Motherland, for his native land, that such love for the Motherland should be an example for present and subsequent generations. Agitation of such positive qualities: as patronage of enlightenment, selfless love for the Motherland, honoring mentors, honesty and courage - the requirement of today when studying his comprehensively exemplary personality on the basis of historical facts.

Another important source of cultural heritage, which reveals the role of moral values that are the basis of a spiritually developed individual, is the religion of zoroastrianism. It is the name of the religion, which later served as one of the sources of the main tenets of Islam. From an early age he was familiar with various religious views and teachings. $\mathrm{He}$ is a native of one of the tribes of Khorezm oasis Spitama. Central Asia is considered to be the birthplace of zoroastrianism. Mary Bones wrote a four-volume work on the history of zoroastrianism. She proved that the birthplace of this religion is Khorezm. It does not belong to national or world religions. This particular religion is based on dualism. Its essence is that there are two beginnings in the world, between which there is a constant struggle, a struggle between darkness and light, a struggle between good and evil. The good beginning is embodied by Ahuramazda, and the evil - Ariman. After all, goodness must win in this fight. Then there will be a 
long good existence in the world. In zoroastrianism it is emphasized that, in addition to the two gods, there are five more that seem to govern various natural processes. It should be emphasized that zoroastrianism consecrates fire, earth, water and air. They were so deified that for the slightest corruption punished mercilessly. For example, for water pollution without hesitation sentenced to death. The doctrine of hell and paradise, of two worlds, of the immortality of the soul was developed in zoroastrianism. According to the ideas of this religion, after the death of the soul of man will live independently.

A great role in the development of the spiritual and moral qualities of the personality of the younger generation belongs to the topics devoted to the study of the moral, ethical and didactic thoughts of the poet Alisher Navoi, who presents them as instructions to young men and women, so that they can better know and understand the nature of their actions.

Navoi describes the young generation this way: "Youth is the spring of the flower bed of life, the light of life." From this spring flowers of joy and fun bloom, bright rays of this light house of delight and joy illuminate. Youth is the power and power of men,in it the beauty of man and his grace. At a young age, all feelings are sharp and the sensations are strong ...". The poet believed that affability, politeness are good for the entire human race, but especially for the younger generation. Thanks to them, it brings up humanity, humanity, mutual understanding. In addition, they must be sincere, far from hypocrisy and lies. "Language," the poet writes, "is a tool of speech.... If he is with the heart, then there is no possibility for lies - a heavy $\sin$...".

While urging young people to master knowledge, Navoi stresses that honoring those people who have taught crafts is their sacred duty:

Behind a drop of a drop of the capped, flow streams of rivers, On the crumbs of knowledge digging, the man wises. Who has been trained to beech one, To reach the truth of the earth, than his teacher will pay, for all earthly riches will not suffice.

According to the poet, the best payment is the kindness that the disciples do, the diligence shown by the younger generation in work.

In the poem "The Confusion of the Righteous" there is a chapter, which describes the life of a talented young man from a poor family, who wants to get an education and dreams of becoming a great scientist. Navoi details the difficulties faced by this young man - lack of housing, funds, hunger, cold.. But despite this, the young man is not discouraged. He firmly, consistently goes to the goal and, in the end, achieves his: becomes a famous scientist.

Navoi not in vain included this story in the poem. He wanted to educate the younger generation on the example of strong, strong-willed, purposeful people. The poet's lines about this young man are not just empathy and compassion. They are admired. [1, 135]

National identity, being the core of national consciousness, is the result of people's comprehension of their belonging to a certain ethnic community and the position of the latter in the system of public relations. National identity can express the interests of both a separate group of ethnic groups (western and eastern Buryats, northern and southern Udmurts), and the nation as a whole (Russians, French). The manifestation of national identity is based on the phenomenon of ethnic identification (ethnicity), i.e. the formation of a sustainable human image of himself as a member of a particular ethnic group.

Historical and cultural determinants of national identity are the historical past and traditions of the people, its established customs and norms of behavior, as well as traditions recorded in oral (folklore) and writing, monuments of culture and art. National identity is almost impossible 
without the functioning of the national language, as language serves as a means of expressing it and forming it.

National identity is manifested in ideas, views, opinions, feelings, emotions, moods and expresses the content, level and peculiarities of the representations of the members of the nation:

- about their particular identity and differences from other communities;

- national values and interests;

- the history of the nation, its present state and prospects for development;

- the place of its socio-ethnic community in internal, interstate and interethnic relations.

The intensity of national identity among individual members of the ethnic community is far from the same. Children do not have it in part or completely. In adult members of the ethnic group, it is usually weakened when they have no contact with representatives of other peoples. This situation is most often found in rural residents, who may have a local or regional identity.

National identity can play a dual role. On the one hand, it can be progressive, if it does not absolutize its community, does not consider it "super-value", ensures a normal attitude towards other peoples. Conversely, national identity is regressive if it is reduced to a narrow framework of clan, religious-nationalist, ideological and political views. Outbreaks of the latest trend take place in various regions and republics of the former USSR. Conflicts and armed struggles in Nagorno-Karabakh, South Ossetia, Georgia, Tajikistan, the war in Chechnya are confirmation of the same trend.

National identity is specifically manifested in attitudes towards other nations. Where close ties and cooperation have always existed between the two ethnic communities, there has usually been a positive attitude towards mutual perceptions that involve tolerance of existing differences. If the contacts between peoples did not affect their life interests, these peoples could be indifferent to each other. It is different when they have been in a state of conflict and hostility for a long time. Then the negative psychological attitude was developed.

Its national interests, reflecting the values of ethnic community and preserving its unity and integrity, play a special role in the life of the nation. They are the most important driving force for the behaviour and activities of individuals and the nation as a whole.

National interests are based on the values of the nation - a set of spiritual ideals of its representatives, which reflects the originality of historical development and culture. National values act as social and psychological regulators of the behaviour of people of the same ethnicity.

National tastes, which represent historically established originality in understanding, assessments and attitudes towards important values, phenomena of life, good and bad among the majority of members of an ethnic community, give the specificity of national interests. National tastes are manifested in the behavior, everyday culture, lifestyle, home decoration, clothing, relations between people, in art, literature, painting, dance and music of representatives of specific ethnic communities.

Its culture and language provide the final expression of the nation's life. National culture is a set of material and spiritual values of a nation, as well as its basic ways of interacting with nature and representatives of other ethnic communities.

The national language, being an effective means of communication, accumulation and expression of experience of the members of the nation, allows to give their culture and all life a specific sound and self-expression. And, of course, on the basis of it arise and constantly appear mutual sympathy, trust of interpersonal relations, compatibility of all representatives of the nation, functioning as a single and indivisible organism. 
The main asset of the nation is made up of its members, who in the interests of their community work hard, realizing their makings and talents, proud of its historical past and merits to humanity, or, on the contrary, feel guilty for the "inferiority" of the ethnic group. Their actions and actions are carried out under the influence of national self-esteem. The latter combines the assessment of the personality of one's abilities and qualities, its role in the ethnic community, and the assessment of the importance of the nation as a whole among other peoples.

High adequate self-esteem is the natural condition of the vast majority of ethnic groups and their representatives. Neither the nation nor the individual as an expression of ethnic identity will ever accept the belittling of their significance, let alone the neglect, and will seek justice by all possible means.

The level of self-esteem and self-esteem of specific people is directly proportional to the sense of national dignity. On the one hand, the higher a person accepts and appreciates the importance of his own personality, the more he feels his unity with the people (no matter how small and insignificant this people may seem to representatives of other ethnic groups), the higher he raises on the bar of importance and level of national dignity. On the other hand, the more developed in the nation as a whole sense of dignity (in historical, cultural or other plans), the more often the individual transfers this importance to the level of his self-esteem. It is no coincidence that many prominent representatives of specific nationalities become a kind of expression of the character and interests of their people, infect many tribesmen with their attitude to their own nation.

A sense of national dignity is people's inner experience of the value, significance and identity of their own nation in the community of different peoples, regardless of any criteria of assessments.
The pride in deeds, thoughts and spiritual wealth of one's ancestors, their people, is part of a sense of national dignity. Respect for positive customs and traditions; love for the native land, a sense of inseparability with its landscape and nature; veneration as immutable examples of culture, folk music, poetic, visual, literary and other works, displaying respect for their authors, etc.

It is in the differentiation and absolutization of certain characteristics of national dignity that the basis of such phenomena as national pride, patriotism, nationalism, chauvinism, cosmopolitanism and some others must be sought.

National pride is patriotic feelings of love for one's homeland and people, awareness of one's belonging to a certain nation, expressed in an understanding of common interests, national culture, language and religion.

National pride is expressed:

. in the nation's desire to contribute to the full development of its traditions, language, material and spiritual culture;

willingness to fight back against those who encroach on the freedom and independence of the nation is disrespectful to its culture and its representatives.

The concept of national pride is close in importance to the concepts of patriotism and love for the Motherland.

Patriotism (from Greek.acomplex phenomenonof social consciousness associated with love for the Motherland, the Fatherland, its people. It manifests itself in the form of social feelings, moral and political principles. The content of patriotism are love for the Fatherland, devotion to the Motherland, pride in its past and present, readiness to serve the interests of the Motherland and protect it from enemies.

Some elements of patriotism in the form of attachment to the native land, language, traditions and customs of their people began to be formed in ancient times. With the emergence of classes and statehood, the content of patriotism becomes 
qualitatively different, because it expresses the attitude to the Motherland, the Fatherland through the specific interests inherent in the class and the state. In the conditions of the formation of nations, the formation of nation states patriotism becomes an integral part of the consciousness of the whole society. Everyone has an idea of feelings of national pride and patriotism, because in any culture, in any people their formation occupies an important place in the education of all generations.

The above allows us to say that there have always been and now there are people for whom the ignition of national hostility is the essence of their existence, who in an atmosphere of hostility feel like a fish in the water and outside such an environment lose ground under their feet. People who despise "foreign people" meet in every nation.

One can say about an individual or a group of persons that they are nationalists or chauvinists, but the people, the nation as a whole can not be. A label of this kind will always be biased and inhumane to any nationality.

\section{Conclusion}

All things considered, the future of Uzbekistan highly depends on the creativeness of the youth. Each can show their potential to be mentally and physically healthy, if they are treated in a right way. The academic discipline "The Idea of National Independence: Basic Concepts and Principles" for high school students, relying on the best examples of freedom-loving ideas of great thinkers, the world discoveries of Al-Khorezmi, AlBeruni, Ulughbek and others, the concept of a just society of Al-Farabi, Amir Timur, the philosophical views of Ibn Sina, the views of Alisher Navoi contributes to the formation of a sense of love and pride of his homeland, nationality, the knowledge of the students of the upper classes of ageold contradictions between good and, virtue and cruelty, creation and destruction; consistent introduction into his consciousness of certain principles and components of ideology labor education, which forms in each person a deep respect for conscientious work for the benefit of man and for the common good, whether mental or physical work. Work is the main source of material and spiritual wealth of a person, the main criterion of his social prestige, the foundation of the development of the sense of the master of his property, the results of his work.

\section{List of literature:}

1. Abdulkhayrov, M.H. Methods of researching texts of works by Alisher Navoi / M.H. Abdulkhayrov // Herald of Chelyabinsk State University. - 2012. - № 12 (266). - S. 134-137.

2. Anthology of Uzbek pedagogy. T. 1 / under Ed. W. Aleuova. - Tashkent : Uk; Ituvchi, 1995. - $478 \mathrm{~s}$.

3. Karimov, I.A. Harmoniously developed generation - the basis of Uzbekistan's progress : President's speech at the 9th session of Oli Mazhlis of the Republic of Uzbekistan, August, 1997. - Tashkent : Shark, 1998. - $55 \mathrm{~s}$.

4. Karimov, I.A. Uzbekistan, aiming for the 21 st century. T. 7 : We are building our future with our own hands / I.A. Karimov. - Tashkent : Uzbekiston, 1999. - 352 s.

5. Nazarova, R.M. Idea of National Independence / R.M. Nazarov. - Tashkent : Molia, 2007. - $156 \mathrm{~s}$.

6. Oripova, N.H. Historical sources of education of devotion to the Motherland / N.H. Oripova, H.H. Rajabova // Young scientist. - 2015. - № 6. - S. 666-668.

7. Timur, A. Ovas timur / A. Timur. Tashkent : Chulpon, 2001. - 233 s. 